\title{
LOSING TIM
}




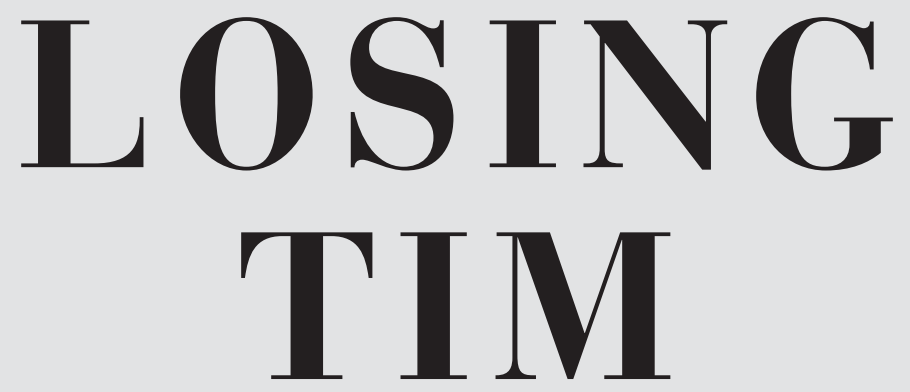

HOW OUR HEALTH AND EDUCATION SYSTEMS

FAILED MY SON WITH SCHIZOPHRENIA

\section{PAUL GIONFRIDDO}

COLUMBIA UNIVERSITY PRESS

NEW YORK 


$$
\begin{gathered}
\text { Columbia University Press } \\
\text { Publishers Since } 1893 \\
\text { New York Chichester, West Sussex } \\
\text { cup.columbia.edu } \\
\text { Copyright (C) } 2014 \text { Columbia University Press } \\
\text { All rights reserved } \\
\text { Library of Congress Cataloging-in-Publication Data } \\
\text { Gionfriddo, Paul. }
\end{gathered}
$$

Losing Tim: How our health and education systems failed my son with schizophrenia / Paul Gionfriddo.

pages $\mathrm{cm}$

Includes bibliographical references.

ISBN 978-o-231-16828-1 (cloth : alk. paper) - ISBN 978-o-231-53715-5 (e-book)

1. Gionfriddo, Tim-Mental health. 2. Schizophrenia in children-PatientsUnited States-Biography. 3. Mental health policy-United States. 1. Title.

$$
\begin{aligned}
& \mathrm{RJ}_{5} \circ 6 . \mathrm{S}_{3} \mathrm{G}_{4} 62014 \\
& 362.2^{\prime} 6092-\mathrm{dc} 23
\end{aligned}
$$

[B]

Columbia University Press books are printed on permanent and durable acid-free paper.

This book is printed on paper with recycled content.

Printed in the United States of America

$$
\text { c } 10987654321
$$

Cover design by Jordan Wannemacher

Cover image is provided courtesy of the author

References to websites (URLs) were accurate at the time of writing.

Neither the author nor Columbia University Press is responsible for URLs that may have expired or changed since the manuscript was prepared. 
To Pam, my love, who supported me - in every way - on this project; and to Tim, whose courage always inspires me. 

I wanted the moments of my life to order themselves like those of a life remembered. You may as well try to catch time by the tail.

-JEAN-PAUL SARTRE, NAUSEA

Grant us wisdom to give priority to those measures

of greatest urgency for the common good of all.

-TIMOTHY GIONFRIDDO, GUEST CHAPLAIN,

CONNECTICUT HOUSE OF REPRESENTATIVES, APRIL 10, 1995 
